\title{
КРАТКИЙ ОБЗОР ДИССЕРТАЦИЙ, ЗАЩИЩЕННЫХ В ДИССЕРТАЦИОННОМ СОВЕТЕ Д 212.253.01 В 2012 г.
}

При ФГБОУ ВПО «Сибирский государственный технологический университет» (Красноярск) работает диссертационный совет Д 212.253.01 по специальностям: 03.01.06 - биотехнология (в том числе бионанотехнологии) по техническим наукам и 05.21 .03 - технология и оборудование химической переработки биомассы дерева; химия древесины по химическим и техническим наукам.

Председатель диссертационного совета - доктор технических наук, профессор, академик РАЕН Юрий Давыдович Алашкевич, заведующий кафедрой «Машины и аппараты промышленных технологий», тел.: (391) 227-34-53.

Заместитель председателя диссертационного совета - доктор технических наук, профессор Рязанова Татьяна Васильевна, заведующая кафедрой «Химическая технология древесины и биотехнология», тел.: (391) 227-52-77.

Ученый секретарь диссертационного совета - доктор технических наук, профессор кафедры «Химическая технология древесины и биотехнология» Елена Владимировна Исаева, тел.: (391) 227-36-54, e-mail: dissovetsibgtu01@mail.ru

\section{Краткий анализ диссертаций, рассмотренных советом}

Тематика рассмотренных советом диссертационных работ в области химических наук касается вопросов химии и физикохимии компонентов биомассы дерева и некоторых видов растительного сырья, продуктов их модифицирования; в области технических наук - вопросов совершенствования технологии производства целлюлозы, древесноволокнистых плит, лесохимических продуктов и биологически активных веществ, разработки оборудования для реализации химической переработки растительного сырья, а также изучения и разработки технологических режимов выращивания микроорганизмов-продуцентов и культур тканей для получения биомассы.

По химическим наукам специальности 05.21.03 советом рассмотрена докторская и две кандидатские диссертации.

В докторской диссертации В.Р. Пена «Динамика щелочных и некоторых окислительных способов делигнификации древесины» разработана новая научная концепция, основанная на принципах полихронности. В частности, доказаны положения о слабом влиянии топологии макромолекулы лигнина на полихронность процесса делигнификации; предложено уравнение для вычисления распределения химических связей полимеров древесины по кинетическим параметрам; представлены математические модели динамики делигнификации.

Создана система практических рекомендаций для реализации теоретических разработок диссертанта на предприятиях отрасли, в частности, представлены рекомендации по усовершенствованию управления варочным процессом. Эффективность предложенных методов подтверждена испытаниями на ОАО «Братский целлюлозно-картонный комбинат». Результаты исследований рекомендовано использовать в практической деятельности целлюлозно-бумажных предприятий.

Работа выполнена в Сибирском государственном технологическом университете. 
В кандидатской диссертации М.Ю. Чепрасовой «Карбоксиметилирование растительного сырья под воздействием микроволнового излучения» изложены закономерности влияния условий карбоксиметилирования древесины сосны, осины, соломы гречихи в среде различных растворителей и целлюлозы в растворе $\mathrm{N}$-метилморфолин-N-оксиде под воздействием микроволнового излучения на свойства получаемых продуктов. Раскрыты условия получения высокозамещенных продуктов карбоксиметилирования, а также изучены сорбционные свойства продуктов карбоксиметилирования растительного сырья. В работе представлены рекомендации по использованию карбокиметилированного растительного сырья в качестве стимуляторов роста растений.

Работа выполнена в Алтайском государственном университете.

В кандидатской диссертации С.А. Аутлова «Превращения древесины под воздействием озона» разработана новая экспериментальная методика получения целлюлозного материала с низким содержанием остаточного лигнина и высоким выходом целлюлозы при непосредственном озонировании древесины в нормальных условиях. Изучена взаимосвязь между содержанием воды в древесине, удельным поглощением озона, степенью его превращения и содержанием лигнина в древесине, составом растворимых ароматических продуктов озонирования древесины, свойствами целлюлозы из озонированной древесины. Представлены рекомендации по использованию полученного целлюлозного материала в качестве адсорбента. Разработанный экологически безопасный способ получения целлюлозного полуфабриката запатентован.

Работа выполнена в Алтайском государственном университете и Московском государственном университете им. М.В. Ломоносова

По техническим наукам специальности 05.21.03 советом рассмотрена одна докторская и 5 кандидатских диссертаций.

В диссертации В.М. Ушановой разработаны теоретические основы ресурсосберегающей комплексной переработки древесной зелени и коры пихты сибирской, позволяющей в едином технологическом процессе получать продукты, обладающие биологической активностью. Изложены закономерности влияния природных факторов на химический состав древесной зелени пихты и получаемые продукты экстрагирования. Изучено влияние технологических параметров на выход и состав биологически активных веществ из древесной зелени и коры пихты. Разработана и внедрена технология переработки древесной зелени и коры пихты; получены опытные партии продуктов: водные, спиртовые и углекислотные экстракты, пихтовое масло.

Результаты работы использованы на предприятиях Красноярска и Красноярского края: в ООО «Флора Биотех», ООО «Эковит», АО «Канский биохимический завод», АОЗТ «ПроТех» и рекомендованы к дальнейшему использованию на предприятиях глубокой химической переработки биомассы дерева, в частности, в лесохимии; в научных, проектно-конструкторских организациях, занимающихся комплексной переработкой растительной биомассы; в вузах при подготовке специалистов лесохимического профиля.

В кандидатской диссертации Е.А. Речкиной установлено, что древесная зелень сосны обыкновенной может быть использована в качестве альтернативного сырья для получения пектиновых веществ. В работе изложены закономерности влияния условий ступенчатого экстрагирования древесной зелени на состав полученных продуктов; раскрыты оптимальные технологические параметры процессов переработки древесной зелени сосны, обеспечивающие высокий выход пектиновых веществ; изучены их физикохимические свойства, позволяющие использовать пектиновые вещества в пищевых целях.

Работа выполнена в Сибирском государственном технологическом университете.

В кандидатской диссертации А.Ю. Сидорова «Пирогенетическая переработка древесины березы, подвергнутой радионуклидному загрязнению» предложены рекомендации по пиролизу древесины с повышенным содержанием радионуклидов и принципиальная технологическая схема производства древесного угля, обеспечивающие получение продуктов пиролиза с показателями, гарантирующими их радиационную безопасность. Доказаны закономерности перехода радионуклидов $137 \mathrm{Cs}$ и $90 \mathrm{Sr}$ в процессе пиролиза древесины березы в зависимости от сырьевых и режимных параметров. Изучено влияние различных факторов на содержание радионуклидов в конечных продуктах пиролиза, разработаны предложения для корректировки 
существующих радиологических норм, установленных СП 2.6.1.759-99, ГОСТ Р 50801-95 для древесного сырья, используемого при пиролизе.

Работа выполнена в Сибирском государственном технологическом университете.

Кандидатская диссертация А.А. Ерофеевой выполнена на тему «Безножевой размол волокнистых полуфабрикатов с учетом реологических особенностей суспензий». В работе дано теоретическое обоснование нового способа определения коэффициента динамической вязкости волокнистых суспензий, основанного на определении реологических характеристик (силы и площади сдвига потока течения волокнистых суспензий). Раскрыты физические явления определения вязкости волокнистых суспензий и противоречия в качественных и количественных зависимостях реологии в сравнении с водой, а также оптимальные параметры безножевого размола с учетом коэффициента динамической вязкости. Изучена взаимосвязь комплексного параметра процесса с бумагообразующими свойствами, прочностными характеристиками образцов бумажных листов и энергосиловыми параметрами размольной установки. Разработки запатентованы.

Результаты работы внедрены в образовательные технологии для специальности «Технологии и оборудование целлюлозно-бумажного производства».

Работа выполнена в Сибирском государственном технологическом университете.

В кандидатской диссертации М.А. Зырянова на тему «Получение полуфабрикатов в одну ступень размола для производства древесноволокнистых плит мокрым способом» решена задача получения полуфабрикатов в одну ступень размола для производства древесноволокнистых плит мокрым способом, что позволило установить количественную оценку качественных показателей, морфологических характеристик древесной массы, физико-механических свойств готовой плиты с технологическими и конструктивными параметрами размольного агрегата. Предложен механизм формирования структуры плиты с учетом особенностей фракционного состава, обосновано положительное влияние мелочи в виде фибриллплазмы группы А и мельштоффа группы Б на плитообразующие свойства.

Результаты работы внедрены на ОАО «Лесосибирский ЛДК №1» и рекомендованы к дальнейшему использованию при проектировании и эксплуатации размольных машин для получения древесноволокнистого полуфабриката в одну ступень размола, позволяющие сократить трудозатраты, уменьшить удельный расход электроэнергии на его производство и себестоимость готовой плиты.

Работа выполнена в Сибирском государственном технологическом университете.

Кандидатская диссертация А.С. Фролова на тему «Разработка оборудования для учета расхода волокнистых суспензий в целлюлозно-бумажном производстве» посвящена вопросам разработки оборудования для учета расхода волокнистых суспензий в целлюлозно-бумажном производстве. Изложены требования к оборудованию с учетом технологических параметров волокнистой суспензии: концентрации волокнистой массы, степени помола и температуры. Проведена модернизация существующих математических моделей влияния параметров волокнистой суспензии на чувствительный элемент вихревого расходомера, позволившая повысить точность прибора в процессе измерения, обеспечить экономию сырья при получении готовой продукции. Разработаны погружные вихревые расходомеры, способные достоверно измерять расход волокнистых суспензий концентрацией до 6\%. Создана методика технологических испытаний погружных вихревых расходомеров. Разработки запатентованы.

Работа выполнена в Сибирском государственном технологическом университете.

По специальности 03.01.06 советом рассмотрены 2 кандидатские диссертации.

В диссертации Е.Г. Киселева «Технико-технологические основы биосинтеза резервных полигидроксиалканоатов водородными бактериями» изложены результаты комплексных исследований кинетических и продукционных характеристик процессов биосинтеза полигидроксиалканоатов водородокисляющими бактериями. В частности, раскрыты закономерности влияния различных субстратов, физиологической активности инокулята, исходной концентрации клеток в инокуляте на продукционные характеристики процесса биосинтеза; изучены кинетические и продукционные показатели бактерий Cupriavidus eutrophus в лабораторных условиях с использованием автотрофного и гетеротрофного субстратов, а также влияние технологических параметров на процесс извлечения полигидроксиалканоатов из биомассы бактерий. 
Технология опытного производства реализована в проекте «Лаборатория биотехнологии новых биоматериалов». Определены перспективы применения разработанной технологии при крупнотоннажном производстве и создана система практических рекомендаций для ведения технологического процесса.

Работа выполнена в Институте биофизики СО РАН и Сибирском федеральном университете.

Диссертация Я.В. Смольниковой на тему «Культивирование Digitalis Purpurea L. в условиях in vitro и получение сердечных гликозидов на ее основе» посвящена вопросам культивирование Digitalis purpurea L.в условиях in vitro и получения сердечных гликозидов на ее основе. В работе раскрыты закономерности влияния способов культивирования на продуктивность каллусной ткани наперстянки пурпурной. Изучено влияние фитогормонов и условий культивирования на цитофизиологические параметры и биохимические характеристики каллусной ткани. Разработаны условия получения альтернативного сырья с повышенным содержанием гликозидов и технологическая схема производства фармацевтических препаратов из каллусной ткани наперстянки пурпурной.

Определены перспективы иммобилизации каллусной ткани для получения высокопродуктивных клеточных линий. Представлены практические рекомендации для извлечения гликозидов из каллусной ткани наперстянки пурпурной.

Работа выполнена в Сибирском государственном технологическом университете.

Все диссертации утверждены.

Ученый секретарь диссертационного совета

Е.В. Исаева 